\title{
Short-term survival of discarded pearl perch (Glaucosoma scapulare Ramsay, 1881) caught by hook-and-line in Queensland, Australia
}

\author{
M.J. Campbell*, M.F. McLennan, W.D. Sumpton \\ Queensland Department of Agriculture, Fisheries and Forestry, Ecosciences Precinct, GPO Box 267, Brisbane, Queensland 4001, Australia
}

\section{A R T I C L E I N F O}

\section{Article history:}

Received 16 April 2013

Received in revised form

20 September 2013

Accepted 2 December 2013

\section{Keywords:}

Glaucosoma scapulare

Pearl perch

Discard survival

Survival experiment

\begin{abstract}
A B S T R A C T
Post-release survival of line-caught pearl perch (Glaucosoma scapulare) was assessed via field experiments where fish were angled using methods similar to those used by commercial, recreational and charter fishers. One hundred and eighty-three individuals were caught during four experiments, of which $>91 \%$ survived up to three days post-capture. Hook location was found to be the best predictor of survival, with the survival of throat- or stomach-hooked pearl perch significantly $(P<0.05)$ lower than those hooked in either the mouth or lip. Post-release survival was similar for both legal $(\geq 35 \mathrm{~cm})$ and sub-legal $(<35 \mathrm{~cm})$ pearl perch, while those individuals showing no signs of barotrauma were more likely to survive in the short term. Examination of the swim bladders in the laboratory, combined with observations in the field revealed that swim bladders rupture during ascent from depth allowing swim bladder gases to escape into the gut cavity. As angled fish approach the surface, the alimentary tract ruptures near the anus allowing swim bladder gases to escape the gut cavity. As a result, very few pearl perch exhibit barotrauma symptoms and no barotrauma mitigation strategies were recommended. The results of this study show that pearl perch are relatively resilient to catch-and-release suggesting that post-release mortality would not contribute significantly to total fishing mortality. We recommend the use of circle hooks, fished actively on tight lines, combined with minimal handling in order to maximise the post-release survival of pearl perch.
\end{abstract}

Crown Copyright @ 2013 Published by Elsevier B.V. All rights reserved.

\section{Introduction}

Pearl perch (Glaucosoma scapulare) are a recreationally and commercially important species found in schools (McKay, 1997) in depths to at least $200 \mathrm{~m}$. G. scapulare is one of the four Glaucosomatids that occur in Australia and is endemic to the east coast between $23^{\circ} \mathrm{S}$ and $33^{\circ} \mathrm{S}$ (McKay, 1997). Although once considered incidental in a multi-species line fishery mainly targeting snapper (Pagrus auratus) in southern Queensland, G. scapulare are now targeted due to a combination of significant reductions in snapper catch rates and more stringent management arrangements in recent years. Recreational and commercial fishers use similar fishing methods to target pearl perch - handlines or rod-and-reel using either monofilament or braided fishing lines rigged so that baited hooks are attached to branch lines located above lead sinkers.

In both Queensland and New South Wales, G. scapulare are managed by minimum legal size and recreational bag limit regulations that result in the mandatory discarding of individuals, termed regulatory discards by Kelleher (2005). The survival of these regulatory discards is unquantified but current management measures would

\footnotetext{
* Corresponding author. Tel.: +61 73255 4229; fax: +61 738461207

E-mail address: matthew.campbell@daff.qld.gov.au (M.J. Campbell).
}

only be effective in conserving stocks if released fish survive capture and subsequent release (Broadhurst et al., 2005a; Butcher et al., 2007, 2008). The survival of discarded individuals represents a large source of uncertainty in estimates of total fishing mortality (Davis, 2002). Generally, total fishing mortality is synonymous with the portion of the catch that is retained and discard mortality is regarded as inconsequential (Muoneke and Childress, 1994). Given Taylor et al. (2012) estimated that $70 \%$ of the 89386 G. scapulare caught by recreational anglers in 2010 were discarded, a low post-release survival rate would significantly increase total fishing mortality. For example, the congeneric West Australian Dhufish (Glaucosoma hebraicum), targeted by recreational and commercial fishers in similar latitudes and depths to G. scapulare on the west coast of Australia, exhibit poor post-release survival, and this has been estimated to increase fishing mortality for this species by $27 \%$ (St. John and Syers, 2005).

The survival of discarded line-caught fish is influenced by a variety of factors (see reviews by Arlinghaus et al., 2007; Bartholomew and Bohnsack, 2005; Muoneke and Childress, 1994). These factors have been the subject of numerous studies in recent years and include hook type or size (Aalbers et al., 2004; Butcher et al., 2008; Cooke et al., 2005; Graves and Horodysky, 2008; Grixti et al., 2007; Mapleston et al., 2008), hooking location (Alós et al., 2008; Butcher et al., 2007; McGrath et al., 2009; Pope and Wilde, 2004), landing 
apparatus (Barthel et al., 2003; Danylchuk et al., 2008; De Lestang et al., 2008) and duration of exposure to air (Gingerich et al., 2007; Reynolds et al., 2009).

Further, given that G. scapulare inhabit relatively deep water (McKay, 1997), bringing a fish to the surface can result in various pressure-related injuries referred to as barotrauma (e.g. St. John and Syers, 2005; Wilde, 2009). Typically, as line-caught fish are brought to the surface, gases within the fish's body expand according to Boyle's Law. As such, the volume of the gas within the swim bladder expands with decreasing pressure (i.e. depth), as do dissolved gases found in the blood and tissue cells, which leave solution and form bubbles (St. John and Syers, 2005). The expansion of gases results in symptoms of barotrauma such as the distension of the body cavity, eversion of the stomach and bulging eyes or exophthalmia (Brown et al., 2010). Prior to rupture, the expanding swim bladder may cause injuries to the adjacent organs (Rummer and Bennett, 2005; Wilde, 2009). Barotrauma has been reported as having a significant effect on the post-release survival of many line-caught demersal species worldwide (e.g. Jarvis and Lowe, 2008; Parker et al., 2006; Rummer and Bennett, 2005; Stewart, 2008).

Given the magnitude of discards, it is prudent to quantify the fate of these discarded animals in order to ensure the efficacy of the management strategies for G. scapulare, particularly as the post-release survival of the congeneric $G$. hebraicum is poor. The objectives of this study were to: (1) quantify the short-term (3-day) survival of G. scapulare; (2) examine factors affecting post-release survival; and (3) investigate whether barotrauma treatment strategies were necessary for this species.

\section{Methods and materials}

The post-release survival field experiments were conducted in an area adjacent to Double Island Point at the southern end of Fraser Island and in the waters off Cape Moreton (Fig. 1), in south east Queensland, Australia. These areas were chosen as they are known to support large populations of G. scapulare and allow for experiments to be conducted in both shallow $(<80 \mathrm{~m})$ and deep $(>80 \mathrm{~m})$ water.

\subsection{Double Island Point - shallow $(<80 \mathrm{~m})$}

G. scapulare habitat in the Double Island Point (Area A in Fig. 1) experimental area consists of rocky reef, particularly surrounding the Wolf Rock Exclusion Zone, and flat, broken gravel substrates. Water depths in these areas range between $30 \mathrm{~m}$ and $80 \mathrm{~m}$.

Post-release survival was assessed using the vertical enclosures described by Brown et al. (2010). Three cylindrical enclosures (hereafter referred to as cages) were constructed of \#36 ply, 4-inch (101-mm) trawl mesh sewn into a cylinder $1.9 \mathrm{~m}$ in diameter and $15 \mathrm{~m}$ deep (see Brown et al., 2010 for an illustration). Seven galvanised steel (12 mm rod) hoops, $1.9 \mathrm{~m}$ in diameter, were used to maintain the cylindrical shape of the cages and were separated by 27.5 meshes $(\sim 2.5 \mathrm{~m})$. The upper-most hoop, positioned at the sea's surface, was welded to an eighth hoop via four lengths of galvanised steel rod ( $12 \mathrm{~mm}$ diameter by $50 \mathrm{~cm}$ in length). This upper section was enclosed by mesh in order to prevent floating animals escaping and provided floating fish protection from predation by birds and sharks. Four large $(50 \mathrm{~cm}$ diameter) polyethylene floats were attached to the inside of the upper enclosure to provide positive buoyancy, while three $13 \mathrm{~kg}$ weights were shackled to the lowermost hoop to ensure the enclosure remained vertical throughout the experiments.

To facilitate retrieval, four lengths of $4 \mathrm{~mm}$ stainless steel chain, each approximately $1.2 \mathrm{~m}$, were shackled to the second-to-lowest hoop and then attached to a $20 \mathrm{~m} \times 12 \mathrm{~mm}$ polyethylene retrieval rope. A dan-buoy with a radar reflector was attached to the upper end of the retrieval rope. The portion of the mesh below the lowermost hoop was gathered together and a drawstring attached in the manner of a trawl-net codend. The 'floor' of the cages was lined with polyethylene shade cloth, a fine mesh screening material used in greenhouses and outdoor areas, to provide the captive animals with some protection from current and also prevent the escape of smaller individuals.

Each cage was anchored to the seafloor via, respectively, $60 \mathrm{~m}$ of $12 \mathrm{~mm}$ polyethylene rope, $10 \mathrm{~m}$ of $12 \mathrm{~mm}$ galvanised steel chain and a $16 \mathrm{~kg}$ fluke-style anchor. The anchor line was then attached to a cage via three bridles of $12 \mathrm{~mm}$ polyethylene rope and a quick-release clip. The cages were deployed close to the shore in approximately $20 \mathrm{~m}$ water depth at the start of each experiment as protection from the south-east winds and southerly current predominate in the area.

G. scapulare were angled from the Fisheries Research Vessel (FRV) Tom Marshall, a $14.5 \mathrm{~m}$ aluminium diesel-powered catamaran, and the MV Makaira, an outboard powered $5.8 \mathrm{~m}$ aluminium centre cabin, with two anglers allocated randomly to each vessel. Individual fish were angled using conventional rod-and-reel employing paternoster rigs (1-3 hooks attached to a $20-30 \mathrm{~kg}$ breaking strain monofilament mainline via $15 \mathrm{~cm}$ of $15-20 \mathrm{~kg}$ breaking strain monofilament branch lines above a lead sinker). The weight of the lead sinker ranged between $110 \mathrm{~g}$ and $450 \mathrm{~g}$ depending on depth and/or current. The hooks used were J-style Mustad "Big Red" in size 5/0 as used by recreational and commercial fishers, baited with pilchards (Sardinops neopilchardus), squid (Family Loliginidae) or mullet (Mugil cephalus).

Once a fish was caught, relevant data were recorded by the angler, including time of day, hook location, hooking-related injuries, handling-related injuries, capture depth and external signs of barotrauma. Fish were then tagged using a numbered Hallprint ${ }^{\mathrm{TM}} \mathrm{T}$-bar tag and placed in a holding container supplied with flow-through seawater. Two 1400 l polyethylene holding tanks were located on the stern deck of the Tom Marshall, while a modified and plumbed 1101 insulated fish box acted as the holding tank on the Makaira. Approximately 45 min after the first fish had been placed in a holding tank, the fish caught on the Tom Marshall were transferred to the holding tank aboard the Makaira before all fish were transported to a pre-determined cage for release. Once at the cage, tag number, the time since capture (i.e. surface interval) and the release condition of each fish were recorded. This procedure was repeated until fishing ceased for the day and repeated on subsequent days. Fishing was carried out over three days, with each cage containing the catch from separate days.

On the fourth day of each experiment, the first cage, containing the catch from the first day of fishing, was retrieved. The cages were designed to be retrieved so that the hoops came together in concertina-fashion, apart from the lower-most hoop, which formed a codend-like compartment at the base of each cage. Once the anchor line had been removed from the cage, via the quick-release clip, the dan-buoy was recovered and the retrieval rope was passed through a small snatch block at the end of a hydraulic crane, mounted on the stern of the Tom Marshall, before being attached to a capstan. Once the cage was aboard, the drawstring was released and the fish removed to one of the 1.4-tonnes holding tanks, at which time all fish were individually assessed for vitality.

\subsection{Cape Moreton - deep $(>80 \mathrm{~m})$}

Given the distances of the fishing grounds from the sheltered waters required to deploy the cages, two methods were employed to hold captured fish from the Cape Moreton area. G. scapulare habitat in the fishing grounds off Cape Moreton consists of rocky reef, wrecks and gravel substrates, with depths ranging between $50 \mathrm{~m}$ 


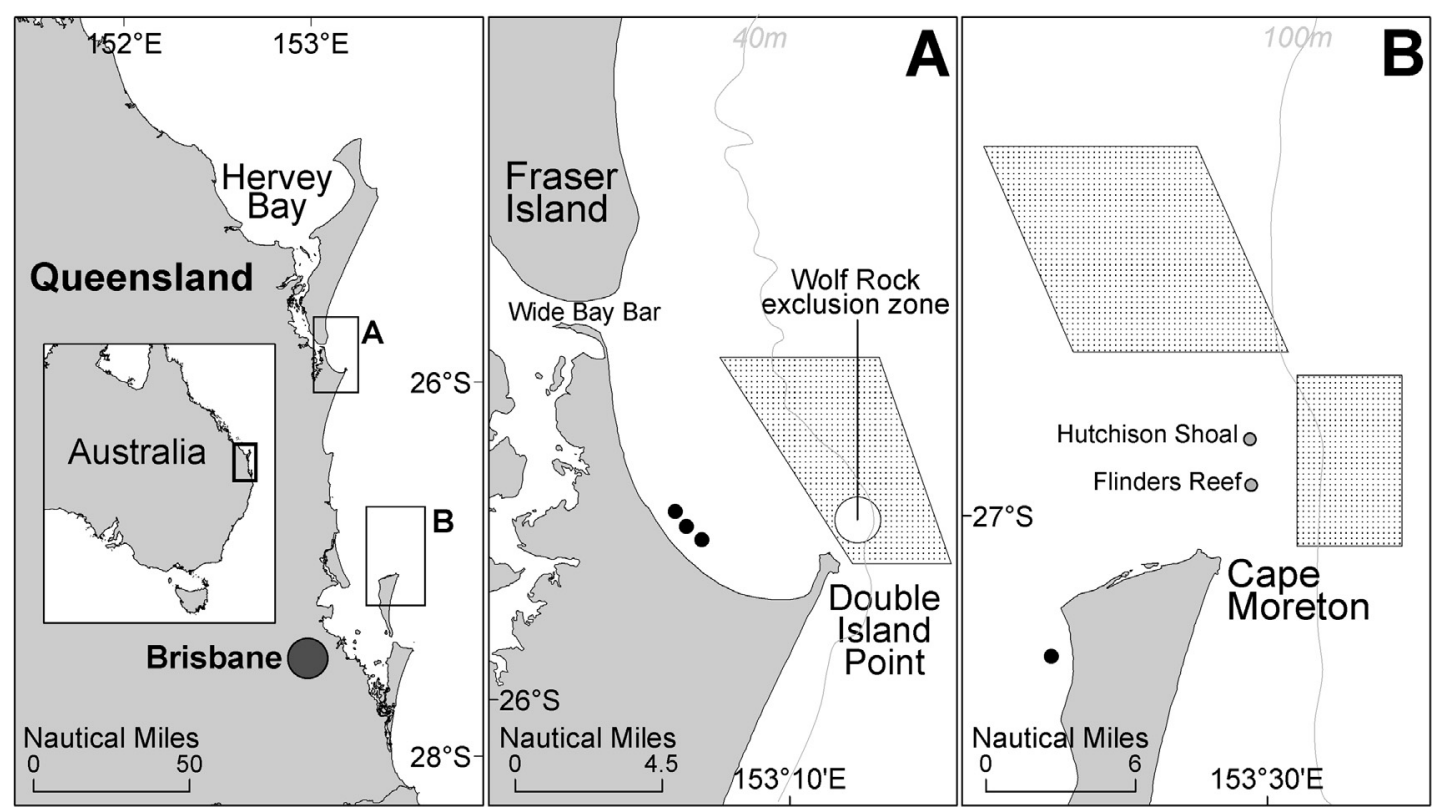

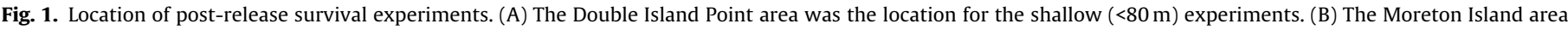
was the location of the deep ( $>80 \mathrm{~m}$ ) experiments. The black circles represent the location of the cages when used and shaded areas represent the fishing grounds.

and $130 \mathrm{~m}$. Depending on prevailing weather and fishing location, captured fish were either left in the holding tanks for a period of 2-3 days or transferred to a modified cage on the western side of Moreton island (see Area B in Fig. 1). One of the cages used in the Double Island Point trips was modified so that fish could be housed in the shelter of Moreton Island in water approximately 5-10 m deep. As such, the cage was modified by removing the middle sections so that the cage was approximately $5 \mathrm{~m}$ deep.

All fishing took place aboard the Tom Marshall using methods described above. Once again, captured fish were individually tagged before transfer to the flow-through holding tanks, after relevant data were recorded by the angler. Once fishing was complete each day, the fish were either left in the on-board holding tanks or removed to the modified cage, depending on the weather conditions and the distance to the modified cage. At the completion of the experiment, all fish were retrieved from the modified cage and placed in the holding tanks, at which time individual vitality was assessed.

In both shallow and deep experiments, all G. scapulare were euthanised and stored in the vessels' on-board freezer. Once back at the laboratory, all fish were dissected in order to determine the extent of barotrauma-related injuries. Before dissection, each fish was immersed in water and air injected into the gut cavity, via a small-bore hypodermic needle, to provide information regarding the likely escape route of swim bladder gases during capture.

Fish were then eviscerated carefully, in order to ensure the swim bladder remained intact. The swim bladder was examined and the presence/absence of a perforation was recorded, as was the size, shape and any signs of healing of perforations. The location of the perforation as a distance from the anterior edge of the swim bladder as a percentage of its length was also recorded. If no perforations were located, the swim bladder was injected with air, via the smallbored hypodermic needle, to assess whether it had healed and to detect the location of any perforation not located by first inspection.

In accord with methods described by Campbell et al. (2011), post-release survival was assessed using generalised linear modelling (GLM) via a binomial distribution with a logit link function, where vitality $-\mathrm{a}$ binary variable with $0=$ dead and $1=$ alive - was the response variable. Water depth and fish length were allocated to categorical variables, with depths allocated to shallow $(<80 \mathrm{~m})$ or deep $(\geq 80 \mathrm{~m})$ and total length allocated to sub-legal $(<35 \mathrm{~cm} \mathrm{TL})$ or legal ( $\geq 35 \mathrm{~cm} \mathrm{TL}$ ). The effects of several qualitative factors on survival were also tested including: signs of barotrauma present (none, exophthalmia, swollen gut cavity, everted stomach); the presence of bleeding (none, light, heavy); hook location (lip, mouth, throat, stomach, outside mouth); holding method (cage, modified cage, onboard tank); and the presence of any injuries (none, eye, gill, jaw, moderate scale loss and heavy scale loss). Trip (A, B, C and D) was also added to the model in order to assess the spatial and temporal variability in post-release survival across all experiments, while surface interval (time between capture and release to holding facility, in minutes) and time held after capture (in hours) were added as covariates. The final model was determined using the RSEARCH function in Genstat (2011), whereby the initial model contained all factors, some of which were removed via forward stepwise elimination until an appropriate model was found based on the adjusted correlation coefficient. Interaction effects were also tested but were excluded from the final model if the deviance ratio of the interaction term was less than an order of magnitude lower than the deviance ratio of either of the main effects (Campbell et al., 2011).

A second GLM was used to determine the effects of the aforementioned factors on barotrauma symptoms using the same procedure. This GLM tested the effect of relevant factors on the presence of barotrauma symptoms, a binomial response variable with $0=$ no barotrauma symptoms and $1=$ barotrauma symptoms present, via a binomial distribution with a logit link function. A third GLM was used to test the effect of various factors on the healing of swim bladder perforations. A swim bladder was classified as healed if (1) the perforation was covered with a film of tissue (Fig. 2) and/or (2) the swim bladder was partially inflated when inspected and/or (3) air could not be injected via the small-bore hypodermic needle. Again, swim bladder healing was assessed using a GLM via a binomial distribution with a logit link function.

\section{Results}

A total of 183 individuals, ranging in size from 19 to $61 \mathrm{~cm} \mathrm{TL}$ were used to assess the post release survival of $G$. scapulare caught during four field trips. Of these, 42 were over the MLS of $35 \mathrm{~cm} \mathrm{TL}$, while 91 were caught in depths less than $50 \mathrm{~m}$. Table 1 provides the 
numbers of individuals in each level of each factor used in the GLM analysis of post-release survival. $94 \%$ of captured fish exhibited no signs of barotrauma, while $93 \%$ were hooked either in the mouth or lip. For individuals presenting with barotrauma symptoms, everted stomachs were confined to the buccal cavity, unlike those observed in $P$. auratus caught incidentally during the field experiments which often had stomachs that protruded well beyond the buccal cavity. Exophthalmia was not observed in any individuals caught during the four field trips.

Of the $141 \mathrm{G}$. scapulare that had air injected into the gut cavity in the laboratory, air was found to escape the gut cavity through the vent in $124(\sim 88 \%)$ individuals. This suggests that, for the most part, as G. scapulare are caught and brought towards the surface, the air within the swim bladder expands until the swim bladder ruptures. At this point, air escapes into the gut cavity and continues to expand as the fish is brought closer to the surface. With decreasing depth, the alimentary tract perforates, allowing the air to escape the gut cavity through the perforated alimentary tract. 62 of the 141 swim

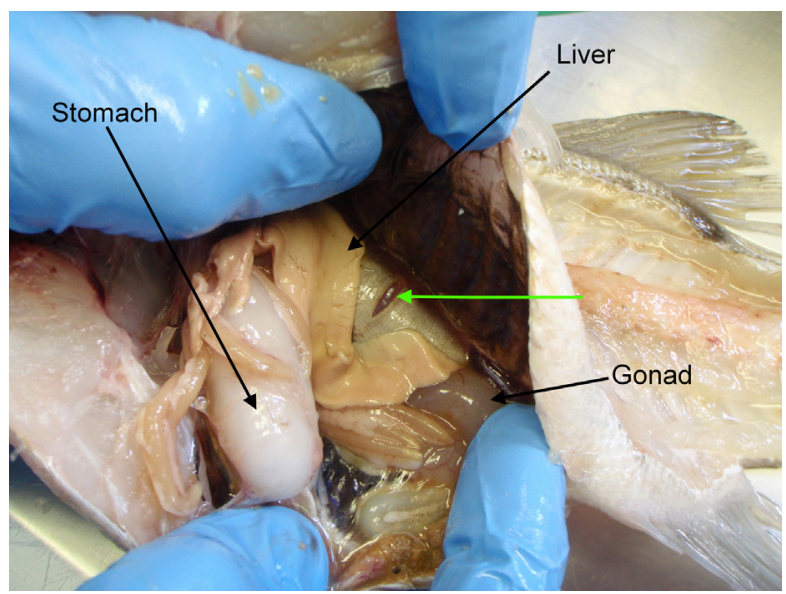

Fig. 2. Signs of healing in the swim bladder of a G. scapulare. Note the film of tissue covering the perforation in the swim bladder highlighted by the arrow.

Table 1

Number of $G$. scapulare as a function of trip, depth, size, depth $\times$ size, observed barotrauma symptoms, location of hook upon capture and storage method.

\begin{tabular}{|c|c|c|}
\hline Factor & Level & Number of observations \\
\hline \multirow[t]{4}{*}{ Trip } & A & 93 \\
\hline & B & 40 \\
\hline & $\mathrm{C}$ & 17 \\
\hline & $\mathrm{D}$ & 33 \\
\hline \multirow[t]{2}{*}{ Depth } & Shallow $(<80 \mathrm{~m})$ & 92 \\
\hline & Deep $(\geq 80 \mathrm{~m})$ & 91 \\
\hline \multirow[t]{2}{*}{ Size } & Legal $(\geq 35 \mathrm{~cm} \mathrm{TL})$ & 42 \\
\hline & Sub-legal $(<35 \mathrm{~cm} \mathrm{TL})$ & 141 \\
\hline \multirow[t]{4}{*}{ Depth $\times$ size } & Deep $\times$ legal & 28 \\
\hline & Deep $\times$ sub-legal & 64 \\
\hline & Shallow $\times$ legal & 14 \\
\hline & Shallow $\times$ sub-legal & 77 \\
\hline \multirow[t]{3}{*}{ Barotrauma symptoms } & None & 172 \\
\hline & Swollen gut cavity & 5 \\
\hline & Everted stomach & 6 \\
\hline \multirow[t]{5}{*}{ Hook location } & Lip & 53 \\
\hline & Mouth & 117 \\
\hline & Throat & 7 \\
\hline & Stomach & 2 \\
\hline & Outside mouth & 4 \\
\hline \multirow[t]{3}{*}{ Holding method } & Cage & 93 \\
\hline & Modified cage & 33 \\
\hline & On-board tank & 57 \\
\hline
\end{tabular}

Table 2

Accumulated analysis of deviance from the final GLM analysis of the post-release survival of line-caught G. scapulare. Hook location had five levels (lip, mouth, throat, stomach and outside) and barotrauma symptoms had three levels (none, swollen gut cavity and everted stomach)

\begin{tabular}{lrrlll}
\hline Factor & d.f. & Deviance & $\begin{array}{l}\text { Mean } \\
\text { deviance }\end{array}$ & $\begin{array}{l}\text { Deviance } \\
\text { ratio }\end{array}$ & $\begin{array}{l}\text { Approx. } \\
\text { chi prob. }\end{array}$ \\
\hline Hook location & 4 & 32.479 & 8.120 & 8.12 & $P<0.001$ \\
Barotrauma symptoms & 2 & 6.544 & 3.272 & 3.27 & $P=0.038$ \\
Residual & 176 & 64.756 & 0.368 & & \\
Total & 182 & 103.779 & 0.570 & & \\
\hline
\end{tabular}
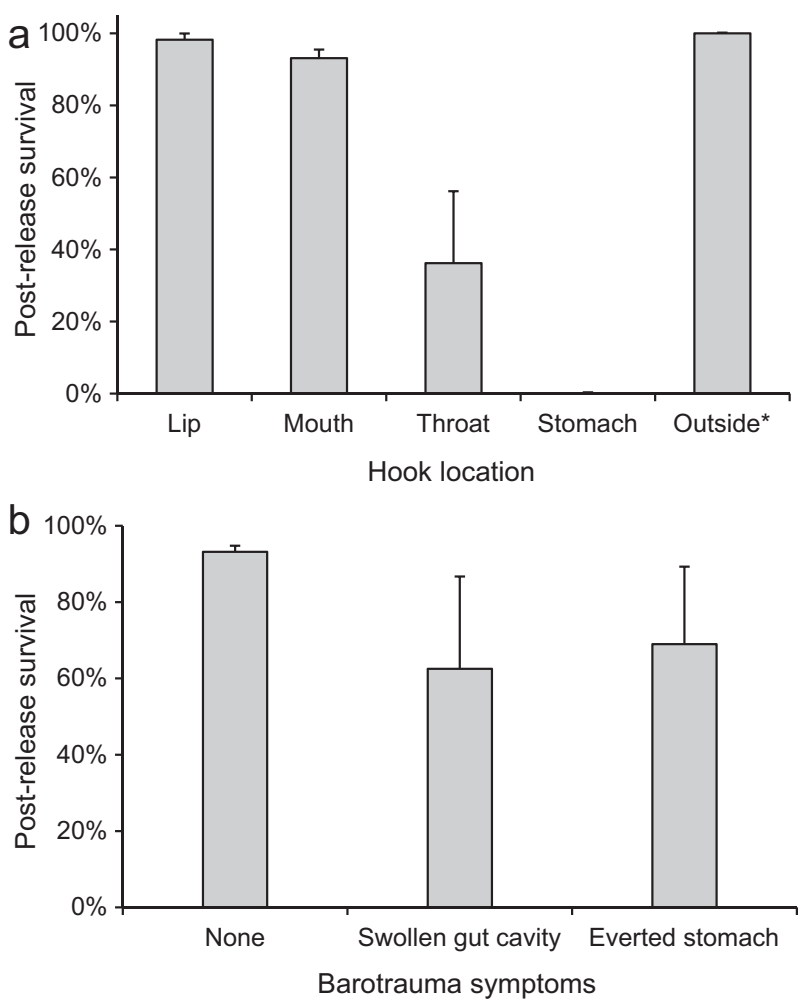

Fig. 3. Short-term (<3 days) adjusted post-release survival of $G$. scapulare as a function of (a) hook location upon capture and (b) observed barotrauma symptoms. *Outside represents hooks located outside the mouth upon capture.

bladders examined were observed to be partially inflated on dissection. Injection of air into partially inflated swim bladders revealed that, in most cases, a thin film of tissue had formed over the perforation (Fig. 2), allowing the retention of swim bladder gases as soon as 1-2 days after capture. This film of tissue remained intact during injection of air into the swim bladder, although in some cases the film ruptured under pressure allowing gases within the swim bladder to escape.

An initial GLM indicated that neither holding facility (cage, modified cage, on-board tank) or "Trip" (A, B, C and D) affected ( $P=0.174$ and $P=0.445$, respectively) post-release survival and, therefore, survival data from the four trips were pooled. The GLM with all terms added indicated that only the hook location upon capture $(P<0.001)$ and observed barotrauma symptoms $(P=0.038)$ significantly affected the post-release survival of $G$. scapulare, with the final model incorporating only these two factors (Table 2). This GLM indicated that the overall short-term post-release survival was $91.6 \%$. No stomach-hooked fish $(n=2)$ and only $36.2 \%$ of throathooked fish $(n=7)$ survived. Fish hooked in the lip, mouth or outside the mouth had survival rates of $98.2 \%, 93.1 \%$ and $99.9 \%$, respectively (Fig. 3a). The survival of throat-hooked fish was found to be significantly lower than both lip-hooked and mouth-hooked 
fish $(P<0.001)$. The low number of stomach-hooked fish made statistical comparison to other categories problematic, with Genstat (2011) suggesting there was no significant difference (i.e. $P>0.1$ ) between the survival of stomach-hooked fish and fish hooked in other locations, despite the fact that no stomach-hooked fish survived.

Observed barotrauma symptoms were also found to have affected the post-release survival of G. scapulare (Fig. 3b). Postrelease survival was highest $(93.2 \%$ ) for fish that exhibited no signs of barotrauma ( $n=174)$. $69.0 \%$ of fish observed with an everted stomach $(n=7)$ survived, while $62.5 \%$ of fish observed with a swollen gut cavity $(n=5)$ survived. The reductions in survival for $G$. scapulare showing signs of a swollen or everted stomach, compared to those without obvious barotrauma symptoms, were statistically significant $(P=0.033$ and $P=0.048$, respectively). The presence of barotrauma symptoms in angled $G$. scapulare was not affected by any factor tested (depth or size category).

Fish size was the only factor found to have significantly affected the incidence of the healing of swim bladder perforations acquired during capture. The incidence of healing in sub-legal G. scapulare was $54 \%$, significantly $(P=0.018)$ higher than in fish of legal size (32.5\%). Mean perforation size in legal and sub-legal G. scapulare was $7 \mathrm{~mm}$ and $6 \mathrm{~mm}$, respectively, and did not differ significantly at the $95 \%$ level of confidence $\left(t_{78}=1.99 ; P=0.21\right)$.

\section{Discussion}

The $91.6 \%$ overall G. scapulare post-release survival rate is at the higher bounds of reported post-release survival of discarded line-caught fish. Bartholomew and Bohnsack (2005) reported that catch-and-release discard survival averaged $82 \%$ (range 5-100\%) in a meta-analysis of 274 studies of post-release mortality of freshwater and saltwater species, with $46 \%$ of survival estimates reported to be above $90 \%$. This estimate included data from a previous study (Muoneke and Childress, 1994), which reported an average postrelease survival rate of approximately $81.5 \%$ from a meta-analysis of 132 separate studies of freshwater and saltwater species.

In accord with Bartholomew and Bohnsack (2005) and Muoneke and Childress (1994), hook location was found to be the best predictor of post-release survival of line-caught G. scapulare. Survival was lower in both throat-hooked and stomach-hooked fish, with no stomach-hooked fish surviving capture. Hook location has been found to be a significant factor affecting the post-release survival of several species in Australia including G. hebraicum (St. John and Syers, 2005), mulloway Argyrosomus japonicus (Butcher et al., 2007) and yellowfin bream Acanthopagrus australis (Broadhurst et al., 2005b). As such, in order to maximise the post-release survival of line-caught $G$. scapulare, it is prudent to highlight methods that reduce the incidence of deep-hooking during capture.

Several authors suggest the use of circle or re-curved hooks, where the point of the hook is perpendicular to the hook shank, in order to prevent the ingestion of hooks (e.g. Butcher et al., 2008; Cooke and Suski, 2004; St. John and Syers, 2005). Further, in order to prevent ingestion of hooks by line-caught species, some authors have employed modifications to J-style hooks such as small pieces of wire attached to the hook shank (Butcher et al., 2008; Willis and Millar, 2001), which prevents hooks from being swallowed. Further, Grixti et al. (2007) reported that baits fished on tight lines were less likely to be swallowed than those fished on slack line.

The removal of hooks has been shown to significantly affect the post-release survival of line-caught fish (Butcher et al., 2007; Wilde and Sawynok, 2009). The removal of hooks from deeplyhooked fish intended for release provides a confounding interaction of three important factors affecting post-release survival - hooking location, trauma associated with hook removal and air exposure or handling time. That is, the retrieval of hooks located in the stomach is likely to require increased handling time and subject the fish to excessive trauma during hook removal. In the current study, only two fish were stomach-hooked, of which one had the hook removed. Both stomach-hooked fish died. Of the five throathooked fish that died, two had the hook removed after capture. As such, there is insufficient information to make recommendations regarding the removal of hooks from deeply-hooked G. scapulare, however, given the significant increases in survival reported by Butcher et al. (2007) it would be beneficial to avoid hook removal in deeply-hooked G. scapulare.

The high survival rates for G. scapulare are in sharp contrast to the poor survival for the West Australian dhufish (G. hebraicum) reported by St. John and Syers (2005). These authors reported 49\% survival for $G$. hebraicum caught at depths to $59 \mathrm{~m}$, with survival as low as $14 \%$ for fish caught between $45 \mathrm{~m}$ and $59 \mathrm{~m}$. However, these authors used much smaller, circular $(75 \mathrm{~cm}$ diameter $)$ cages compared to those used in the current study. Brown et al. (2010) found that the post-release survival of red emperor (Lutjanus sebae) was $0 \%$ in small cages compared to $98.4 \%$ using the larger cages deployed in the current study. St. John and Syers (2005) reported that duration of caging affected the mortality of G. hebraicum, while this factor was found not to have significantly affected the survival of G. scapulare in the current study. It is possible, therefore, that the results reported by St. John and Syers (2005) underestimate the post-release survival of $G$. hebraicum.

Only $11(6 \%)$ of the 183 G. scapulare caught during the survival experiments exhibited barotrauma symptoms. In contrast, exophthalmia and swollen gut cavities occurred in a high proportion ( $\sim 45 \%$ and $\sim 58 \%$, respectively) of G. hebraicum caught in depths between $45 \mathrm{~m}$ and $59 \mathrm{~m}$ (St. John and Syers, 2005). These symptoms were also present in G. hebraicum caught in shallower water (15-29 $\mathrm{m}$ and 30-44 $\mathrm{m}$ ) although at lower frequencies. The incidence of barotrauma symptoms was significantly lower in G. scapulare caught during the current study with only $9 \%$ and $3 \%$ of fish caught in deep water $(\geq 80 \mathrm{~m})$ and shallow water $(<80 \mathrm{~m})$, respectively, exhibiting barotrauma symptoms. Barotrauma symptoms were milder in G. scapulare, with no incidence of exophthalmia observed even from $130 \mathrm{~m}$ water depth.

Contrasting post-release survival rates in congeneric species was also reported by Brown et al. (2010), who found that two Lutjanids, L. sebae and Lutjanus campechanus, had post-release survival rates of $98.4 \%$ and $77 \%$ (as reported by Rummer and Bennett, 2005), respectively. Brown et al. (2010) offer no explanation as to the cause of the difference in mortality rates. St. John and Syers (2005) attributed the very low post-release survival rates of $G$. hebraicum to their susceptibility to barotrauma, highlighting that the blood chemistry of $G$. hebraicum impairs their recovery from high activity levels or pressure changes due to line capture. Further, although speculative, the difference in post-release survival between these two Glaucosomatids may be the respective habitats favoured by each species, with $G$. hebraicum most often associated with hard reef (Hesp et al., 2002; McKay, 1997), while McKay (1997) states that G. scapulare are a "midwater feeder moving well up off the bottom". As such, G. scapulare may be better able to adapt to changes in ambient pressure compared to G. hebraicum, resulting in milder and lower incidences of barotrauma symptoms in the former.

The stages of barotrauma observed in G. scapulare are consistent with those reported by Brown et al. (2010) for L. sebae. Bubbles were often observed rising to the surface as individuals were being angled due to the perforation of the alimentary tract and the gases escaping the gut cavity, with larger bubbles observed in greater depths suggesting that the rupture of the alimentary tract occurred at greater depths. As such, we assumed that all G. scapulare caught as part of the experiments suffered barotrauma and were likely to have had the swim bladder rupture at some point during capture. 
The rapid healing of the perforated swim bladder is consistent with studies by Burns and Restrepo (2002) and Nichol and Chilton (2006) who reported the healing of swim bladder perforations in red snapper (L. campechanus) and Pacific cod (Gadus macrocephalus), respectively, occurred within four days. Further, both Humborstad and Mangor-Jensen (2013) and Midling et al. (2012) reported that the swim bladder of the Atlantic cod (Gadus morhua) is functional within days of perforation and capable of maintaining buoyancy.

The speed at which the swim bladder heals may be important in the survival of G. scapulare in the longer term. A ruptured swim bladder can result in an inability to maintain position at a given depth without significant finning due to negative buoyancy (Render and Wilson, 1994). G. scapulare were observed finning while in holding tanks aboard the Tom Marshall, with the caudal fin making S-shaped movements while the pectoral fins moved in a figureeight pattern in order to maintain position within the tank due to the slight current generated by the seawater in-flow. This may lead to exhaustion in released fish, with increased predation expected in fish released with a perforated swim bladder.

In conclusion, G. scapulare appear to be a resilient species with regard to catch-and-release, with our experiments indicating that more than $90 \%$ survive capture and release after 3 days. G. scapulare swim bladders rupture during ascent from depth, before the alimentary tract ruptures, allowing swim bladder gas to escape via the stomach, resulting in low incidences of obvious barotrauma symptoms. Hook location was found to be the best predictor of post-release survival, with the survival of stomach- and throathooked fish significantly lower than those hooked in the mouth or lip. Regulatory discards are relatively low and are not likely to significantly impact estimates of fishing mortality. Using traditional fishing methods - baited J-style hooks on paternoster rigs - very few fish are stomach-hooked resulting in low post-release mortality. The use of circle hooks, fished actively on tight lines, combined with minimal handling will maximise the post-release survival of G. scapulare. Any hooks located in the throat or stomach should be left in situ, with the line cut outside of the mouth.

\section{Acknowledgements}

This work was funded by the Fisheries Research and Development Corporation (FRDC Project Number 2008/015) and the Queensland Department of Agriculture, Fisheries and Forestry and we thank them for their continued support. We are grateful to Sean Maberly for his seamanship, patience and enthusiasm on the FRV Tom Marshall during field work. Thanks also to Keith Chilcott, Frank Lavarie and Geoff Sorrell for assisting in the capture of pearl perch during field work. We gratefully acknowledge Marco Kienzle and Dr. David Mayer for their assistance in statistical analyses and direction in developing sampling protocols in the initial stages of the field work. We also thank Dr. Tony Courtney and Dr. Warwick Nash for providing comments on earlier drafts of the manuscript.

\section{References}

Aalbers, S.A., Stutzer, G.M., Drawbridge, M.A., 2004. The effects of catch-and-release angling on the growth and survival of juvenile white seabass captured on offset circle and j-type hooks. N. Am. J. Fish. Manag. 24, 793-800.

Alós, J., Cerda, M., Deudero, S., Grau, A.M., 2008. Influence of hook size and type on short-term mortality, hooking location and size selectivity in a Spanish recreational fishery. J. Appl. Ichthyol. 24, 658-663.

Arlinghaus, R., Cooke, S.J., Lyman, J., Policansky, D., Schwab, A., Suski, C., Sutton, S.G., Thorstad, E.B., 2007. Understanding the complexity of catch-and-release in recreational fishing: an integrative synthesis of global knowledge from historical, ethical, social, and biological perspectives. Rev. Fish. Sci. 15, 75-167.

Barthel, B.L., Cooke, S.J., Suski, C.D., Philipp, D.P., 2003. Effects of landing net mesh type on injury and mortality in a freshwater recreational fishery. Fish. Res. 63, $275-282$

Bartholomew, A., Bohnsack, J.A., 2005. A review of catch-and-release angling mor tality with implications for no-take reserves. Rev. Fish Biol. Fish. 15, 129-154.
Broadhurst, M.K., Butcher, P.A., Brand, C.P., Porter, M., 2005a. Ingestion and ejection of hooks: effects on long-term health and mortality of angler-caught yellowfin bream Acanthopagrus australis. Dis. Aquat. Organ. 74, 27-36.

Broadhurst, M.K., Gray, C.A., Reid, D.D., Wooden, M.E.L., Young, D.J., Haddy, J.A., Damiano, C., 2005b. Mortality of key fish species released by recreational anglers in an Australian estuary. J. Exp. Mar. Biol. Ecol. 321, 171-179.

Brown, I.W., Sumpton, W.D., McLennan, M.F., Mayer, D., Campbell, M.J., Kirkwood, J., Butcher, A., Halliday, I., Mapleston, A., Welch, D., Begg, G.A., Sawynok, B., 2010. An improved technique for estimating short-term survival of released line-caught fish, and an application comparing barotrauma-relief methods in red emperor (Lutjanus sebae Cuvier 1816). J. Exp. Mar. Biol. Ecol. 385, $1-7$.

Burns, K.M., Restrepo, V., 2002. Survival of reef fish after rapid depressurization: field and laboratory studies. In: American Fisheries Society Symposium, 30, American Fisheries Society, pp. 148-151.

Butcher, P.A., Broadhurst, M.K., Reynolds, D., Cairns, S.C., 2008. Influence of terminal rig configuration on the anatomical hooking location of line-caught yellowfin bream, Acanthopagrus australis. Fish. Manag. Ecol. 15, 303-313.

Butcher, P.A., Broadhurst, M.K., Reynolds, D., Reid, D.D., Gray, C.A., 2007. Release method and anatomical hook location: effects on short-term mortality of anglercaught Acanthopagrus australis and Argyrosomus japonicus. Dis. Aquat. Organ. 74, $17-26$.

Campbell, M.J., Officer, R.A., Prosser, A.J., Lawrence, M.L., Drabsch, S.L., Courtney, A.J. 2011. Survival of graded scallops Amusium balloti in Queensland's (Australia) trawl fishery. J. Shellfish Res. 29, 373-380.

Cooke, S.J., Barthel, B.L., Suski, C.D., Siepker, M.J., Philipp, D.P., 2005. Influence of circle hook size on hooking efficiency, injury, and size selectivity of bluegill with comments on circle hook conservation benefits in recreational fisheries. N. Am. J. Fish. Manag. 25, 211-219.

Cooke, S.J., Suski, C.D., 2004. Are circle hooks an effective tool for conserving marine and freshwater recreational catch-and-release fisheries? Aquat. Conserv.: Mar. Freshwater Ecosyst. 14, 299-326.

Danylchuk, A.J., Adams, A., Cooke, S.J., Suski, C.D., 2008. An evaluation of the injury and short-term survival of bonefish (Albula spp.) as influenced by a mechanical lip-gripping device used by recreational anglers. Fish. Res. 93, 248-252.

Davis, M.W., 2002. Key principles for understanding fish bycatch discard mortality. Can. J. Fish. Aquat. Sci. 59, 1834-1843.

De Lestang, P., Griffin, R., Allsop, Q., Grace, B.S., 2008. Effects of two different landing nets on injuries to the barramundi Lates calcarifer, an iconic Australian sport fish. N. Am. J. Fish. Manag. 28, 1911-1915.

Genstat, 2011. Version 14. VSN International Ltd., Hemel Hempstead.

Gingerich, A.J., Cooke, S.J., Hanson, K.C., Donaldson, M.R., Hasler, C.T., Suski, C.D., Arlinghaus, R., 2007. Evaluation of the interactive effects of air exposure duration and water temperature on the condition and survival of angled and released fish. Fish. Res. 86, 169-178.

Graves, J.E., Horodysky, A.Z., 2008. Does hook choice matter? Effects of three circle hook models on postrelease survival of white marlin. N. Am. J. Fish. Manag. 28, 471-480.

Grixti, D., Conron, S.D., Jones, P.L., 2007. The effect of hook/bait size and angling technique on the hooking location and the catch of recreationally caught black bream Acanthopagrus butcheri. Fish. Res. 84, 338-344.

Hesp, S.A., Potter, I.C., Hall, N.G., 2002. Age and size composition, growth rate, reproductive biology, and habitats of the West Australian dhufish (Glaucosome hebraicum) and their relevance to the management of this species. Fish. Bull. $100,214-227$

Humborstad, O.-B., Mangor-Jensen, A., 2013. Buoyancy adjustment after swimbladder puncture in cod Gadus morhua: an experimental study on the effect of rapid decompression in capture-based aquaculture. Mar. Biol. Res. 9, 383-393.

Jarvis, E.T., Lowe, C.G., 2008. The effects of barotrauma on the catch-and-release survival of southern California nearshore and shelf rockfish (Scorpaenidae Sebastes spp.). Can. J. Fish. Aquat. Sci. 65, 1286-1296.

Kelleher, K., 2005. Discards in the world's marine fisheries. An update. FAO Fish. Tech. Pap. 470, 131.

Mapleston, A., Welch, D., Begg, G.A., McLennan, M.F., Mayer, D., Brown, I.W., 2008. Effect of changes in hook pattern and size on catch rate, hooking location, injury and bleeding for a number of tropical reef fish species. Fish. Res. 91, 203-211.

McGrath, S.P., Butcher, P.A., Broadhurst, M.K., 2009. Effects of salinity and anatomical hook location on the mortality and physiological response of angled-andreleased sand whiting Sillago ciliata. J. Fish Biol. 74, 220-234.

McKay, R.J., 1997. Pearl Perches of the World (Family Glaucosomatidae). An Annotated and Illustrated Catalogue of the Pearl Perches known to Date. FAO, Rome, Italy.

Midling, K.Ø., Koren, C., Humborstad, O.-B., Sæther, B.-S., 2012. Swimbladder healing in Atlantic cod (Gadus morhua), after decompression and rupture in capturebased aquaculture. Mar. Biol. Res. 8, 373-379.

Muoneke, M.I., Childress, W.M., 1994. Hooking mortality: a review for recreational fisheries. Rev. Fish. Sci. 2, 123-156.

Nichol, D.G., Chilton, E.A., 2006. Recuperation and behaviour of Pacific cod after barotrauma. ICES J. Mar. Sci./J. Conseil 63, 83-94.

Parker, S.J., McElderry, H.I., Rankin, P.S., Hannah, R.W., 2006. Buoyancy regulation and barotrauma in two species of nearshore rockfish. Trans. Am. Fish. Soc. 135, 1213-1223.

Pope, K.L., Wilde, G.R., 2004. Effect of catch-and-release angling on growth of largemouth bass, Micropterus salmoides. Fish. Manag. Ecol. 11, 39-44

Render, J.H., Wilson, C.A., 1994. Hook-and-line mortality of caught and released red snapper around oil and gas platform structural habitat. Bull. Mar. Sci. 55, 1106-1111. 
Reynolds, D.P., Broadhurst, M.K., Butcher, P.A., Rolfe, M., 2009. Effects of anglerinduced exercise and air exposure on the mortality of mouth-hooked yellowfin bream (Acanthopagrus australis). J. Appl. Ichthyol. 25, 100-103.

Rummer, J.L., Bennett, W.A., 2005. Physiological effects of swim bladder overexpansion and catastrophic decompression on red snapper. Trans. Am. Fish. Soc. 134, $1457-1470$.

St. John, J., Syers, C.J., 2005. Mortality of the demersal West Australian dhufish, Glaucosoma hebraicum (Richardson 1845) following catch and release: the influence of capture depth, venting and hook type. Fish. Res. 76, 106-116.

Stewart, J., 2008. Capture depth related mortality of discarded snapper (Pagrus auratus) and implications for management. Fish. Res. 90, 289-295.
Taylor, S., Webley, J., McInnes, K., 2012. 2010 Statewide Recreational Fishing Survey. State of Queensland, Department of Agriculture, Fisheries and Forestry, Brisbane Queensland, pp. 82, http://www.daff.qld.gov.au/28_18273.htm

Wilde, G.R., 2009. Does venting promote survival of released fish? Fisheries 34 20-28.

Wilde, G.R., Sawynok, W., 2009. Effect of hook removal on recapture rates of 27 species of angler-caught fish in Australia. Trans. Am. Fish. Soc. 138, 692697.

Willis, T.J., Millar, R.B., 2001. Modified hooks reduce incidental mortality of snapper (Pagrus auratus: Sparidae) in the New Zealand commercial longline fishery. ICES J. Mar. Sci. 58, 830-841. 